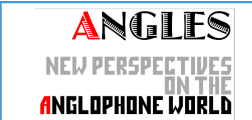

\section{Angles}

New Perspectives on the Anglophone World

$4 \mid 2017$

Unstable States, Mutable Conditions

\title{
Victorian Rainbow Makers: Variations on Colour Poetics
}

\section{Charlotte Ribeyrol}

\section{(2) OpenEdition \\ 1 Journals}

\section{Electronic version}

URL: https://journals.openedition.org/angles/1548

DOI: $10.4000 /$ angles. 1548

ISSN: 2274-2042

\section{Publisher}

Société des Anglicistes de l'Enseignement Supérieur

\section{Electronic reference}

Charlotte Ribeyrol, "Victorian Rainbow Makers: Variations on Colour Poetics", Angles [Online], 4 | 2017, Online since 01 April 2017, connection on 07 June 2022. URL: http://journals.openedition.org/angles/ 1548 ; DOI: https://doi.org/10.4000/angles.1548

This text was automatically generated on 7 June 2022

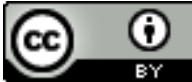

Angles est mise à disposition selon les termes de la Licence Creative Commons Attribution 4.0 International. 


\title{
Victorian Rainbow Makers: Variations on Colour Poetics
}

\author{
Charlotte Ribeyrol
}

1 In his 1871 reissuing of George Field's Chromatography, Thomas Salter retraced the invention of the first artificial dyes made from coal-tar, ${ }^{1}$ which the older chemist, who had died in 1854, could not have witnessed. Although all the poetic quotations in Field's part-literary, part-scientific discussion of colouring practices were excised from this edition, Salter waxed lyrical when he evoked the wealth of new chromatic terms made available by the expanding chemical and textile industries:

The violet mauve led the way, followed by the red magenta, the blue azuline, the yellow phosphine, the green emeraldine, the orange aurine, by purple, and brown, and black. [...] The world rubbed its eyes with astonishment; and truly it seemed almost as wonderful to produce the colours of the rainbow from a lump of coal, as to extract sunshine from cucumbers.

The history of these colours reads more like a romance than a sober story. (Salter 162-3)

2 In the preface to his 1993 study entitled The Rainbow Makers, Anthony S. Travis resorts to similar literary comparisons to retrace the history of the synthetic dyestuffs industry:

This was the first act of a drama that rapidly unfolded across Europe, and, somewhere along the way, caused Perkin to become a legend in the history of modern science and technology. The story of Perkin's mauve and the astonishing rainbow of successors that appeared during the second half of the nineteenth century is the subject of this book. (Travis 9)

3 Like Salter, Travis exploits the fictional - or rather "dramatic" - potential of William Perkin's accidental discovery which gave rise to a "mauve mania" ${ }^{2}$ throughout Europe. Perkin himself is here turned into a "legend" - that is to say an almost mythical character whose story is to be told and read (legenda).

4 If such literary images are rather unexpected in a scientific work, when it comes to studies of colour the metaphor of the rainbow is not infrequently used. ${ }^{3}$ In ancient philosophy, the problematic ontological status of colour - as shifting and elusive as the 
rainbow itself - had often been the object of deprecatory comments, in particular by Plato and Aristotle. ${ }^{4}$ It was Isaac Newton's pioneering experimentum crucix which ushered colour into the field of modern science by explaining that white light is made up of the seven colours of the spectrum, drawing on a comparison with the phenomenon of the rainbow as a direct illustration of his theory. ${ }^{5}$ This experiment paved the way for the modern science of colorimetrics ${ }^{6}$ which emerged in the 1860 s. The second half of the $19^{\text {th }}$ century was indeed a turning point in the experience of colour as both its production and perception became the object of increased scientific scrutiny. This, in turn, prompted diverse reactions from poets and artists, just as Newton's prism experiment had triggered off numerous responses from Romantic writers, from Goethe to Keats.

But contrary to $19^{\text {th }}$-century chemists, whose colourful inventions Salter poetically compared to muticoloured "flowers" in a "garden of tropic tints", Newton was perceived by Romantic poets, suspicious of rationalist classifications, as a defacer of the beauty of nature, an un-maker of rainbows. If the romantic rebellion against Newton's scientific approach to colour as light has been rather well-documented, the conflicting attitudes of late $19^{\text {th }}$ century poets towards modern rainbow makers, experimenting on colouring matter, have been strangely overlooked. In his evocation of the multiple applications of aniline dyes, Salter does, however, mention their use by painters (as aniline components may have been used to make certain types of madder pigments), which he immediately discards as the new colours were soon discovered to be as fugitive as the rainbow (Salter 163). But despite his use of literary images, he does not envisage to what extent the new chromatic terminology devised by chemists may have also destabilized the poetic or rather poietic process - from the Greek poien, meaning "to make". How did Victorian writers respond to the industrial production of these modern rainbows which were widely discussed in the press at the time? In order to explore the creative tensions brought about by such chromatic instability, this paper will focus on the poetic inscription of ancient and modern colouring practices in the works of John Ruskin, William Morris, Walter Pater and Oscar Wilde.

The first part of my analysis will retrace the Victorian posterity of Keats's antiNewtonian "rainbow-sided" Lamia, a poetic plea in favour of chromatic exuberance as opposed to the fixity and strictures of scientific rule. This will be followed by a reflection on nostalgic reponses to the colour revolution brought about by the discovery of aniline dyes, in particular in the works of Ruskin, Morris and Pater who craved for ancient Greek colour-weaving or poikilia - a Hellenic term encoding dappledness as well as versatility. In keeping with the moral ambiguity suggested by this Victorian poikilia, the focus of the final section will be on colour-perception and late $1^{\text {th }}$ century pseudo-scientific tracking of perceptual deviance, from Homer's purple rainbow to the "indigomania" of fin-de-siècle artists and poets.

\section{The romantic texture of the rainbow, from Keats to Wilde}

7 In The Art of England (1883), Ruskin praised the chromatic harmony of William Holman Hunt's Our English Coasts (Strayed Sheep) (1852):

It showed us, for the first time in the history of art, the absolutely faithful balances

of colour and shade by which actual sunshine might be transposed into a key in 
which the harmonies possible in material pigments should yet produce the same impression upon the mind which were caused by light itself. (Ruskin, The Art of England v. 23: 272-3 ${ }^{7}$

8 If the experience of painters mixing their colours on the palette contradicted Newton's findings (as mixing all the colours does not produce white light but brown matter, a distinction which would later be theorised as the opposition between substractive and additive mixture), Ruskin here clearly strove to overcome the difference between immaterial light and the materials at the artist's disposal. ${ }^{8}$ Contrary to the NeoImpressionists who would further experiment with optical mixture a few years later, Ruskin's obsession with the ethereal nature of colour was not only an aesthetic stance: it also had a personal resonance. His unease with chromatic materiality, a materiality deeply connected to the feminine body, is well illustrated by his ambiguous response to the meretricious hues of his beloved Venice. ${ }^{9}$ This may explain some of his references to the rainbow in Stones of Venice, which he refused to describe in Newtonian terms:

In that heavenly circle which binds the statutes of colour upon the front of the sky, when it became the sign of the covenant of peace, the pure hues of divided light were sanctified to the human heart forever; nor this, it would seem, by mere arbitrary appointment, but in consequence of the fore-ordained and marvellous constitution of those hues into a sevenfold, or, more strictly still, a threefold order, typical of the Divine nature itself. (Ruskin, Stones of Venice v. 10: 174-5)

9 Although the passage in Genesis 9:13 does not refer to any of the colours of the sacred bow, Ruskin is careful to replace Newton's sevenfold spectrum by a trinity of holy colours. ${ }^{10}$ This is certainly part of Ruskin's effort to celebrate "Colour," as "the purifying or sanctifying element of material beauty" (Modern Painters v. 7: 417). As noted by John Barrie Bullen, Ruskin, who had been living with the bride of his unconsummated marriage in Venice in 1851, constructed "an elaborate theory which sought to disengage colour (and Venetian colour in particular) from the material and the sensual, and connect it with something more ethereal - love" (Bullen 130-1).

Drawing on the Romantic rhetoric of Keats and Wordsworth, Ruskin equally believed that the beautiful rainbow, symbolising God's covenant of mercy with Man, was threatened by the dissecting impulse of modern science:

I much question whether any one who knows optics, however religious he may be, can feel in equal degree the pleasure or reverence which an unlettered peasant may feel at the sight of a rainbow. (Ruskin, Modern Painters v. 5: 387)

11 This opposition between the analytical logic of science and the aesthetic pleasure elicited by natural phenomena is also found in Wilde's "Garden of Eros" (1881), a poem set in a hellenized Oxford, which pays tribute to all of Wilde's poetic models, from Keats to Morris:



Here the verb "analyzed" needs to be taken in its etymological sense, from the Greek ana (meaning "up, throughout") and lysis ("a loosening," from lyein, "to unfasten"), suggesting separation or division as opposed to the weaving process of poetic creation. The allusion is clearly to Keats's poem "Lamia": 
Do not all charms fly

At the mere touch of cold philosophy?

There was an awful rainbow once in heaven:

We know her woof, her texture; she is given

In the dull catalogue of common things.

Philosophy will clip an Angel's wings,

Conquer all mysteries by rule and line,

Empty the haunted air, and gnomed mine -

Unweave a rainbow, as it erewhile made

The tender-person'd Lamia melt into a shade. (Keats, "Lamia”, II, 11. 229-38: 176-7).

This passage has often been quoted in scientific studies on colour although this particular section of the poem does not evoke any of the colours of the rainbow. The quotation should indeed be more clearly contextualised: Keats wrote this poem in 1819, two years after a dinner organised by Benjamin Haydon on 28 December 1817 during which Charles Lamb claimed that "Newton had destroyed all the poetry of the rainbow by reducing it to the prismatic colours" (Lamb qtd. in Gigante 433). Although in the original manuscript of "Lamia" Keats had written "destroy a rainbow" to echo Lamb's anti-Newtonian assertion (Gigante 438), the notion of "unweaving" in the final version further highlights the "ana-lytical" logic of science. The ten-line quotation is a poetic illustration of this destructive impulse: Nature's sublime, rich ("aw-ful") bow is here clipped by "cold philosophy". The passage is dominated by alliterations in [k] ("catalogue", "common", "clip", "conquer") suggesting the harshness of scientific classifications, narrowing the poet's creative horizon. Responding to limitation and dissonance (exemplified by the eye rhyme "fly" / "philosophy"), the poet resorts to sensuous imagery, emphasizing the texture of a feminised rainbow ("her woof, her texture"), a plea for sensual haptics rather than Newtonian optics. And if colour is strangely absent from this passage, it is because Lamia, the iridescent eponymous heroine, is colourless and bloodless after Apollonius, the white-haired, marmoreal spirit of "cold philosophy" and former mentor of her lover Lycius, has just exposed her true serpentine nature during their wedding ceremony. Prior to this public revelation (based on book 4 of Philostratus' Life of Apollonius of Tyana), the poet had celebrated the beauty of the "rainbow-sided" Lamia whose exuberant colours could hardly be contained within the poetic form:

She was a gordian shape of dazzling hue,

Vermilion-spotted, golden, green, and blue;

Striped like a zebra, freckled like a pard,

Eyed like a peacock, and all crimson barr'd;

And full of silver moons, that, as she breathed,

Dissolv'd or brighter shone, or interwreathed

Their lustres with the gloomier tapestries

- So rainbow-sided. (Keats, "Lamia”, I, 1l. 47-54: 162)

Lamia's iridescence stems from her colourful, serpentine scales, the interwreathing of which reflect her versatile nature. According to Denise Gigante, this passage signals a monstrous metamorphosis reminiscent of Dr Frankenstein's use of galvanic electricity to give life to his creature: "Both scenes of creation were intended to produce objects of beauty, and both erupt in monstrosity" (440). But this was also a means for Keats to reject the fixity and limitation of scientific rules, defied by the chromatic explosion of Lamia's excessive colours, in turn textually suggested by the multiplicity of poetic enjambments: "the threatened reduction of life to physical organization spark(s) a countervision of life as excess" (Gigante 442). 

trans-formation is not, however, so much a matter of form but rather a colouring process, which recalls the colours of the humours in the Hippocratic corpus (Barra 2009).

the serpent now began

To change; [...]

The colours all inflam'd throughout her train, She writh'd about, convuls'd with scarlet pain:

A deep volcanian yellow took the place

of all her milder-mooned body's grace. (Keats, “Lamia”, I, 1l. 146-56: 164-5)

This monstruous metamorphosis textually suggested by the multiplicity of poetic enjambments was certainly a means for Keats to reject the fixity and limitation of scientific rules, defied by the chromatic explosion of Lamia's excessive colours.

Ruskin knew Keats's poem well, as he references it twice in Modern Painters. He was, however, more than uneasy with the figure of the "Lamia", the colourful serpentine daemon in Greek mythology, as noted by Marc Simpson (1982). The Pre-Raphaelite painter William Holman Hunt, whose use of prismatic colour Ruskin celebrated, often resorted to Ruskinian rhetoric when evoking his painting materials. One of his favourite colours was, for instance, the costly ultramarine, described as a "heavenly" hue in his one of his lectures on pigments (Hunt 486) ${ }^{11}$ which he concludes in typically Ruskinian fashion with a plea to "direct [...] inert matter to a spiritual end" (499).

In spite of his indebtedness to Ruskin's Biblical tone, Hunt equally drew on Keats's poetry (which he illustrated throughout his life) for one of his representations of the Lady of Shalott (see Figure 1). Crowned with a rainbow, the Lady indeed appears as a Lamia-like weaver of "a magic web with colours gay" (Tennyson 1.38 in Roberts 22), yielding to chromatic temptation at a moment of chaos expressed by a chromatic vortex. The entangled colourful threads echo the serpentine curves of the Lady's body covered by an iridescent bodice, which is more reminiscent of Keats's poem than Tennyson's, who does not describe this particular episode. 
Figure 1: William Holman Hunt, The Lady of Shalott (c.1890-1905)



Wadsworth Atheneum Museum of Art, Hartford, Connecticut. Source: https://www.khanacademy.org/ humanities/becoming-modern/victorian-art-architecture/pre-raphaelites/a/waterhouse-the-lady-ofshalott

The correlation between serpent and rainbow was certainly not invented by Keats. The Hellenic context of "Lamia" reminds us that such comparisons may also be found in the archaic Greek poets, notably Homer, whose works Keats had read in Chapman's translation. In Book XI of the Iliad for instance, the serpent and the rainbow are brought together. This may be due to their common arched shape but also to their implicit association with a form of chromatic instability, equally encoded by the Greek notion of poikilia, which Diodorus Siculus would later use to describe the dangerous consequences of an ominous rainbow woven onto a fabric in the sanctuary of Demeter. ${ }^{12}$ This poikilia not only sheds light on the ambiguity of the rainbow and iridiscent creatures in ancient Greek texts, but also on the tension between material and spiritual colours in Victorian poetry and painting.

\section{Weaving ancient colours: nostalgic poikilia}

As shown by many of his poems on Greek subjects, Keats's relation to Hellenic culture was material, sensual and "instinctive" 13 rather than purely philological and intellectual. This stress on the materiality of ancient Greek culture is also to be found in the writings of Victorian authors who embraced Heinrich Schliemann's archeological discoveries in the 1870s, unearthing hitherto unknown aspects of the archaic Hellenic world, such as the mythical site of Troy. Walter Pater, for instance, was particularly keen on celebrating the wealth of archaic Greek craftsmanship as he sought "to relieve the air of our galleries and museums of their too intellectual greyness" ("The 
Beginnings of Greek Sculpture" v. 6: 191). Drawing on Homer's epics as his main source to retrieve the material splendour of these "minor" arts and crafts, notably "the curious wood-work, the carved ivory, the embroidery and coloured stuffs, on which the Greeks set much store" (187-8), he introduces the key notion of poikilia, defined as "an Asiatic curiousness", and which Adeline Grand-Clément has recently analysed as central to the aesthetics of archaic poetry, and expressing "the more generic ideas of variety, versatility, intricacy, and complexity." (2015:406) Pater closely associates this poikilia with the centrifugal forces of Hellenic culture, an "Asiatic tendency" which, he notes, "Plato" was "desirous to cure":

There is the centrifugal, the Ionian, the Asiatic tendency, flying from the centre, working with little forethought straight before it, in the development of every thought and fancy; throwing itself forth in endless play of undirected imagination; delighting in brightness and colour, in beautiful material, in changeful form everywhere, in poetry, in philosophy, even in architecture and its subordinate crafts. In the social and political order it rejoices in the freest action of local and personal influences; its restless versatility drives it towards the assertion of the principles of separatism, of individualism-the separation of state from state, the maintenance of local religions, the development of the individual in that which is most peculiar and individual in him. (Pater, "The Marbles of Aegina" v. 6: 252-3)

The more conservative and colourless Plato (Pater, Plato and Platonism v. 5: 147) was indeed extremely wary of the instability and "restless versatility" conveyed by the idea of poikilia. He shunned colour as conducive to a form of deceptive cosmetics, resorted to this term associated with the changing scales of the serpent to compare the democratic regime "to a shimmering coat that might appeal to women and children" (Plato, Republic 8.557c and 558c, qtd. in Grand-Clément 2015: 407). If the adjective poikilos was but rarely applied to the rainbow in ancient Greek texts, it was indeed frequently used to describe the dazzling effects of colourful textiles, often in connection either with serpentine creatures, so as to suggest the idea of chromatic instability. ${ }^{14}$

However, by the end of the $19^{\text {th }}$ century, the hegemony of Plato in Hellenic studies was being increasingly questioned or rather reinterpreted in more subversive ways, including by Pater himself, as archeological discoveries revealed that Hellenic art was not confined to the miracle of $5^{\text {th }}$ century Athens. In his essays on Greek art, posthumously published as Greek Studies in 1895, it is Homer (rather than Plato) whom Pater invokes as an alternative "authority" on Greek arts and crafts, so as to weave chromatic materiality back into the Hellenic heritage so often confined to the marmoreal purity of its statues. Among the Asiatic divinities he celebrates in these essays, the feminine god Dionysos features prominently. Pater, in "The Bacchanals of Euripides," describes the Eastern divinity as "somewhat womanly," and wearing "the fawn-skin with its rich spots" (v. 6: 62). As Robert Crawford explains, the term used by Euripides to describe this fawn-skin representing the elusive, dappled nature of Dionysos, is "poikilos" (qtd in Dowling 1) - just like the anti-Apollonian "rainbowsided" Lamia whom Keats had described as "freckled like a pard". In "A Study of Dionysus" (1876) as well as in "The Bacchanals of Euripides", Pater stresses the feminine dimension of the archaic Dionysian cult. Retracing the origins of the god in primitive Greek religion, he describes such female spirits as:

[...] weavers or spinsters, spinning or weaving with airiest fingers, and subtlest, many-coloured threads, the foliage of the trees, the petals of flowers, the skins of the fruit, the long thin stalks on which the poplar leaves are set so lightly that 
Homer compares to them, in their constant motion, the maids who sit spinning in the house of Alcinous. (Pater, "A Study of Dionysus" v. 6: 12)

In Wilde's review, a link is therefore implicitly established between Morris's poetic reappropriation of an unexpectedly colourful Hellenic past and his own craftsmanship, notably though his practice of colour weaving. Morris himself considered the poetic process as a form of ancient craft: "If a chap can't compose an epic poem while he's weaving tapestry, he had better shut up, he'll never do any good at all." (qtd in Latham x) This also resonates with his Merton Abbey venture. In 1881, Morris had indeed founded his own dye works at Merton Abbey, using ancient recipes to retrieve colouring practices which the chemical industry had rendered obsolete. Countering modern chemical endeavours so as to follow in Homer's colourful footsteps, Morris wove meaning and beauty back into a world obsessed by scientific progress. This is what he wrote in 1889 about the impact of the invention of aniline dyes on the art of dyeing:

[...] there is an absolute divorce between the commercial process and the art of dyeing. Any one wanting to produce dyed textile with any artistic quality in them must entirely forgo the modern and commercial methods in favour of those which are at least as old as Pliny, who speaks of them being old in his time. (Morris 29 Oct. 1889)

Morris's, Ruskin's and Pater's nostalgia for ancient colouring practices, in particular for the art of colour-weaving or poikilia, was therefore a means to challenge not only the Victorian conception of a hegemonic Greek canon but also the hubris of modern rainbow makers. 


\section{New chromatic impressions: colour and artifice} suspicious as Morris and Hunt concerning all the colours devised by modern science. His own discussion of the aniline revolution in The Queen of the Air (1869) sheds light on what he believed to be both an artistic and semantic deprivation brought about by the new chromatic terminology invented by late $19^{\text {th }}$-century chemists which he contrasts with the more poetic colour-sense of Homer:

I was long puzzled by Homer's calling the sea purple; and misled into thinking he meant the colour of cloud shadows on green sea; whereas he really means the gleaming blaze of the waves under wide light. [...] And then, last of all, to keep the whole history of it in the fantastic course of a dream, warped here and there into wild grotesque, we moderns, who have preferred to rule over coal-mines instead of the sea [...] have actually got our purple out of coal instead of the sea! And thus, grotesquely, we have had enforced on us the doubt that held the old word between blackness and fire, and have completed the shadow, and the fear of it, by giving it a name from battle, 'Magenta'. (Ruskin, "The Queen of the Air" v. 19: 379-80)

Ruskin's meandering syntax attempts to capture the variegation which the Greeks of the archaic age were so sensitive to. The quotation culminates in the final denigration of the grotesque and martial connotations of modern "Magenta", the name of the second most famous aniline dye after mauve, which - ironically - Perkin had initially wished to call "Tyrian purple". The new terminology instead reflects a world gone astray due to its materialistic aspirations in contrast to the poetic wealth suggested by the Greek term for purple (porphureos), which Homer equally applied to the rainbow in the Iliad, Book XVII (547-552), as Ruskin also notes: ${ }^{17}$

'As when Jupiter spreads the purple rainbow over heaven, portending battle or cold storm, so Athena, wrapping herself round with a purple cloud, stooped to the Greek soldiers, and raised up each of them.' Note that purple, in Homer's use of it, nearly always means - fiery, - full of light. It is the light of the rainbow, not the colour of it, which Homer means you to think of. (Ruskin, "The Queen of the Air" v. 19: 330)

In keeping with the dazzling beauty of ancient fabrics dyed in the purple of the murex snail, the Homeric rainbow appears as a beautiful texture enveloping the sacred body of Athena, which allows Ruskin to reconcile once more chromatic materiality and colour as light. Ruskin's reflection on the Greek colour-sense also underlines its creative dimension, by emphasizing the various chromatic and light effects on the modern reader/viewer (addressed as "you").

However, some Victorian thinkers were even more "puzzled" by what they described as the chromatic oddities of the ancient Hellenes. This was the case of W.E. Gladstone who, in his Studies on Homer and the Homeric Age, discussed the "paucity" of chromatic occurrences in the Homeric epics. The rainbow appears as a case in point:

Homer's perception of the prismatic colours or colours of the rainbow, which depend on the decomposition of light by refraction, and a fortiori of their compounds, was, as a general rule, vague and indeterminate. [...] It is in viewing the rainbow as a type of what is awful, that we are to find the reason of Homer's simply treating it as dark, and not as a series and system of colours. Perhaps we ought not to overlook the possibility that Homer may also mean to compare the shifting hues of the serpent with the varied appearance of the rainbow. [...] I conclude, then, that the organ of colour and its impression were but partially developed among the Greeks of the heroic age. (Gladstone 1858 v. 3: 483-8) 
ther than reflecting the perceptual deficiencies of the ancient Greeks, this passage reveals Gladstone's posture as a hegemonic post-Newtonian observer. Gladstone went even further in a later essay entitled "The Colour-Sense", in which he drew on the findings of the Austrian ophtalmologist Hugo Magnus to reach the conclusion that the eye structure of the ancient Greeks was not sufficiently developed to perceive colour properly (Gladstone 1877).

This discussion of the Greek colour-sense reflects the growing concern of certain contemporary scientists with colour perception. The second half of the $19^{\text {th }}$ century was indeed a period during which the experience of colour was the focus of increased scientific attention both in terms of its perception and of its production. "Pathologies" such as colour-blindness or synaesthesia, which artists claimed as enriching for the creative process, came under medical scrutiny as potential signs of more dangerous perversions. Just as Gladstone had interpreted Homer as colour-blind, deviant colour perception became the object of heated discussion by pseudo-scientists such as Max Nordau who, in his essay Degeneration drew on the excessive colour sensitivity of certain poets and artists as an index of their troubled, if not hysterical nature. In his essay dedicated to Cesare Lombroso, the founder of anthropological criminology, Nordau targeted many so-called "delirious" British writers and artists such as Ruskin, Swinburne, Morris, Hunt or Wilde, drawing on their metaphors and chromatic choices as a sign of their mental and moral degeneracy:

He does not let the external world express a mood, but makes it tell a story; he changes its appearance according to the character of the event he is describing. [...] This is a purely delirious idea. It corresponds in art and poetry to hallucination in mental disease. It is a form of mysticism, which is met within all the degenerate Just as in Swinburne the mill-water drives 'small red-leaves,' and, what is certainly more curious, 'little white birds' - when everything is going on well, and on the other hand is lashed by snow and hail, and tosses shattered boats about, if things take an adverse turn; so, in Zola's Assommoir, the drain from a dyeing factory carries off fluid of a rosy or golden hue on days of happiness, but a black or gray-coloured stream if the fates of Gervaise and Lantier grow dark with tragedy. (Nordau 98)

This mocking of the modern colour-sense reaches a climax in Nordau's analysis of the colourful and often synaesthetic works of French poets such as Charles Baudelaire, Théophile Gautier, or Arthur Rimbaud and of fin-de-siècle painters like Édouard Manet whose presumed optical deficiencies he was equally keen to stigmatise:

There is hardly a hysterical subject whose retina is not partly insensitive. [...] Thus originate the violet pictures of Manet and his school, which spring from no actually observable aspect of nature, but from a subjective view due to the condition of the nerves. When the entire surface of walls in salons and art exhibitions of the day appears veiled in uniform half-mourning, this predilection for violet is simply an expression of the nervous debility of the painter. (Nordau 27-9)

Unfolding all the colours of the rainbow, Nordau lists the various retinal diseases he believes contemporary painters were suffering from. His approach is strikingly normative, in particular when he analyses the "depressing" predilection for unnatural "violet" which the Impressionists had indeed adopted both as an alternative to lightless black and as the modern colour par excellence, in the wake of the aniline revolution. ${ }^{18}$ In this sense, Nordau's diatribe echoes Joris-Karl Huysmans's 1880 denunciation of the "indigomania" of contemporary painters (by indigo ${ }^{19}$ he meant a violet blue) which was also based on the more or less spurious theories of contemporary scientists: 
Their retinas were sick; the case studies stated by oculist Galezowski [...] on the atrophy of multiple eye fibres, in particular the loss of the perception of green, which is the prodrome of this type of affection were clearly theirs because green has almost disappeared from their palettes, whereas blue which impresses the retina most remains, dominates and drowns everything on their canvases. (Huysmans 103-4, my translation)

The idea that modern artists were insensitive to "green" is strangely reminiscent of Gladstone's observation that "no green" (Symonds v. 1: 596-7) was to be found in the Homeric texts (contrary to "purple", porphureos, applied to the sea as well as to the rainbow), a clear sign, according to him, that the ancient Greeks had been colour-blind.

However, Huysmans would later change his mind concerning the Impressionists and even embrace their chromatic eccentricities, as shown by the predilection of Des Esseintes, the hero of A Rebours (1884), for the aniline suggestions of mauve:

Disregarding entirely the generality of men whose gross retinas are capable of perceiving neither the cadence peculiar to each color nor the mysterious charm of their nuances of light and shade; ignoring the bourgeoisie, whose eyes are insensible to the pomp and splendor of strong, vibrant tones; and devoting himself only to people with sensitive pupils, refined by literature and art, he was convinced that the eyes of those among them who dream of the ideal and demand illusions are generally caressed by blue and its derivatives, mauve, lilac and pearl grey. (Huysmans 46)

Perceptual hyperaesthesia is here presented as the chromatic sign of the refined taste of the dandy as opposed to the common perception of the ordinary man.

A Rebours was to become one of the key intertextual references of Wilde's Picture of Dorian Gray (1890) whose eponymous protagonist falls prey to the influence of the "poisonous" French book. The two authors clearly shared a taste for arcane chromatic terminology, as shown by this passage about gems directly inspired by the enumerative style of Huysmans. The following quotation closely connects colour as light and chromatic materiality, culminating with the partly oxymonoronic image of the "broken rainbow of the milky opal":20

He would often spend a whole day settling and resettling in their cases the various stones that he had collected, such as the olive-green chrysoberyl that turns red by lamplight, the cymophane with its wirelike line of silver, the pistachio-coloured peridot, rose-pink and wine-yellow topazes, carbuncles of fiery scarlet with tremulous, four-rayed stars, flame-red cinnamon-stones, orange and violet spinels, and amethysts with their alternate layers of ruby and sapphire. He loved the red gold of the sunstone, and the moonstone's pearly whiteness, and the broken rainbow of the milky opal. (Wilde, The Picture of Dorian Gray v. 12: 217-8)

41 Among all of the rainbow notations in the novel, violet and mauve are frequent, although Wilde's response to this modern colour seems more than ambiguous at times. On the one hand, Lord Henry expresses distrust as to the shifting new dyes, advising Dorian never to "trust a woman who wears mauve, whatever her age may be", and yet in the same paragraph he admits having once worn "nothing but violets all through one season, as a form of artistic mourning for a romance that would not die." (162-3) One of the flowers that Wilde himself flaunted was the famous green carnation, which he and his acolytes wore at the premiere of Lady Windermere's Fan in 1892. The artificial colour of this flower was obtained by plunging its stem into aniline malachite green. ${ }^{21}$ Robert Hichens then turned this aniline green carnation into a symbol of decadent aesthetics in his eponymous novel published in 1894, a roman à clef featuring Esmé 
Amarinth as the witty Oscar Wilde figure, who composes a "rainbow catch" about a "rose-white youth" for a group of choir boys (again, colour is the lure) (Hitchens 112):

'The flower is a detail. I worship it.'

'Do you regard it as an emblem, then?'

'No. I hate emblems. [...] I wear this flower because its colour is exquisite. I have no other reason.'

'But its colour is not natural.'

'Not yet. Nature has not followed art so far. She always requires time. Esmé invented this flower two months ago. Only a few people wear it, those who are the followers of the higher philosophy.' (Hitchens 91-2)

Epitomized by the aniline green carnation, the "fairy wand" of the modern rainbow makers therefore also served the creative genius and originality of the dandy-poet, whose artificial inventiveness outweighs the powers of Nature, indeed turning "the waste land" into "a garden of tropic tints".

Wilde's ambiguous attitude towards the aniline revolution reflects the multiple tensions at work in the field of late $19^{\text {th }}$ century chromatic experience and experimentation. Resisting the classifying impulse of modern colorimetrics as well as the normative strictures of medical discourses on colour perception, many avant-garde Victorian writers and artists strove to exalt either the exuberance of colour and/or its sacredness. In this context, the ephemeral rainbow was woven back into the poetic texture so as to become the shifting symbol for these chromatic debates confronting prismatic colours and the materiality of pigments and dyes, on the one hand, and modern and Homeric colour-perception, on the other.

Such tensions may also be found in an early $20^{\text {th }}$-century short story by Richard Le Gallienne entitled "The Maker of Rainbows" (1912). A nostalgic dandy from the 1890s, Le Gallienne was an admirer of Keats whom he called "the poet of the rainbow" (1904: $\mathrm{xi}$ ), as well as of Pater, and Wilde. Drawing on popular folklore as well as on the model of Wilde's children's stories, Le Gallienne describes in "The Maker of Rainbows" the magical encounter between a mysterious, old knife-grinder humming a "strange singsong" and a group of poverty-stricken children and villagers in the heart of a November darkness. The first miracle which the stranger performs is to turn a little girl's tear into a beautiful rainbow. The second is to restore a mad, old woman to youth, beauty and sanity. In both instances, Le Gallienne asserts the magical powers of elusive colour, a colour resisting not only the unweaving force of science (the tear is recomposed into a rainbow rather than de-composed as in Newton's experimentum crucis) but also the normative strictures of the medical logos. Contrary to the children who embrace the colourful miracle, the more materialistic villagers accuse the stranger of being the devil, to which he replies:

I am the maker of rainbows. I am the alchemist of hope. To me November is always May, tears are always laughter that is going to be, and darkness is light misunderstood. The sad heart makes its own sorrow, the happy heart makes its own joy. The harvest is made by the harvestman - and there is nothing hard or black or weary that is not waiting for the magic touch of hope to become soft as a spring flower, bright as the morning star, and valiant as a young runner in the dawn. (Le Gallienne 1912: 12)

Here Le Gallienne replaces the chemical transformation of coal into artificial colouring substances by a colourful alchemy of hope. However, when, at the very end of the story, the stranger mentions the legendary pot of gold at the foot of the rainbow, all the greedy villagers set off in search of the imaginary treasure, which the children alone 
know was, in fact, the miracle of fugitive colour made ever-lasting, thanks to the wealth of aesthetic experience:

Then the villagers looked at one another, and said over and over again, "A pot of gold!"

And they took cloaks and walking-staves and set out to accompany the old visitor; but when they reached the outskirts of the village there was no sign of him. He had mysteriously disappeared.

But the children never forgot the rainbows. (Le Gallienne 1912: 13).

\section{BIBLIOGRAPHY}

Barra, Edoarda. "Des Humeurs, des couleurs et des remèdes." In L'antiquité en couleurs: catégories, pratiques, représentations. Ed. Marcello Carastro. Grenoble: Jérôme Millon, 2009. 153-62.

Blaszczyk, Regina Lee. The Color Revolution. Cambridge, Mass.: MIT Press, 2012.

Bullen, John Barrie. Continental Crosscurrents: British Criticism and European Art 1810-1910. Oxford: Oxford UP, 2005.

Carman, Bliss et al. eds. The World's Best Poetry. Philadelphia: John D. Morris and co, 1904, 10 vols. Davreu, Robert. Keats, Seul dans sa Splendeur. Paris: Orphée La Différence, 1990.

Dowling, Linda. "Ruskin's Pied Beauty and the Constitution of a 'Homosexual' Code." Victorian Newsletter 75 (1989): 1-8.

Dubois, Arnaud, Jean-Baptiste Eczet, Adeline Grand-Clément and Charlotte Ribeyrol. Arcs-en-ciel et couleurs, regards comparatifs. Paris: CNRS Editions, forthcoming.

Garfield, Simon. Mauve. New York and London: Norton and Company, 2000.

Gigante, Denise. "The Monster in the Rainbow: Keats and the Science of Life." PMLA 117.3 (May 2002): 433-48. https://www.jstor.org/stable/823143

Gladstone, W.E. Studies on Homer and the Homeric Age. Oxford: Oxford UP, 1858. 3 vols.

Gladstone, W.E. “The Colour-Sense.” The Nineteenth Century 8 (1877): 366-88.

Grand-Clément, Adeline. La Fabrique des couleurs, Histoire du paysage sensible des Grecs anciens (VIIIe s.- début du Ve s. avant notre ère.). Paris: De Boccard, 2011.

Grand-Clément, Adeline. "Poikilia". In A Companion to Ancient Aesthetics. Eds. Pierre Destrée and Penny Murray. London: Blackwell, 2015. 406-21.

Hichens, Robert. The Green Carnation. London: The Unicorn Press, 1949 (1894).

Hunt, William Holman. "The Present System of Obtaining Materials in Use by Artist Painters as Compared with that of the Old Masters." Journal of the Society of Arts 28.1431 (23 April 1880): 485-99.

Huysmans, Joris-Karl. “L'Exposition des Indépendants en 1880," republished in L'Art Moderne, Paris: Stock, 1902 (1883). 
Huysmans, Joris-Karl. Against the grain (A Rebours). Trans. John Howard. New Kork: Lieber \& Lewis, 1922.

Johnston, Sean F, A History of Light and Colour Measurement, Science in the Shadows. Bristol and Philadelphia: Institute of Physics Publishing, 2001.

Keats, John. The Poetical Works of John Keats. Ed. H.W. Garrod. Oxford: Oxford UP, 1992 (1956).

Latham, David Ed. Writing on the Image: Reading William Morris. Toronto: U. of Toronto P., 2007.

Le Gallienne, Richard. “The Maker of Rainbows.” In The Maker of Rainbows and other fairy tales and fables. New York and London: Harper \& Brothers Publisher, 1912. 7-13.

Le Gallienne, Richard. “What's the Use of Poetry?” In The World's Best Poetry. Ed. Bliss Carman, et al. Philadelphia: John D. Morris and Co, 1904, vol.7.

Lichtenstein, Jacqueline. La couleur éloquente, Paris: Flammarion, 1999.

Morris, William. The William Morris Internet Archive. https://www.marxists.org/archive/morris/ works/index.htm

Newton, Isaac. Philosophical Transactions of the Royal Society 80 (19 Feb. 1671/2): 3075-87.

Nordau, Max. Degeneration. London: William Heinemann, 1895.

Pater, Walter. The Works of Walter Pater. London: Macmillan, 1922-29, 9 vols.

Prins, Yopie. “Greek Maenads, Victorian Spinsters.” In Victorian Sexual Dissidence. Ed. Richard Dellamora. Chicago and London: U. of Chicago P., 1999. 43-82.

Roberts, Adam Ed. Alfred Tennyson, The Major Works. Oxford: Oxford UP, 2000.

Ross, Iain. Oscar Wilde and Ancient Greece. Cambridge: Cambridge UP, 2013.

Ruskin, John. The Complete Works of John Ruskin. Ed. E.T. Cook and Alexander Wedderburn. London: George Allen, 1903-1912, 39 vols.

Salter, Thomas W. Ed. Field's Chromatography. London: Winsor and Newton, 1871.

Simpson, Marc. “The Dream of the Dragon: Ruskin's serpent imagery.” In The Ruskin Polygon, Essays on the Imagination of John Ruskin. Eds. John Dixon Hunt and Faith M. Holland. Manchester: Manchester UP, 1982. 21-43.

Symonds, John Addington. The Letters of John Addington Symonds. Eds. Schueller, Herbert M. and Robert L. Peters. Detroit: Wayne State UP, 1967-1969, 3 vols.

Travis, Anthony S. The Rainbow Makers: The Origins of the Synthetic Dyestuffs Industry in Western Europe. Bethlehem: Lehigh UP, 1993.

Vernant, Jean-Pierre, and Marcel Détienne. Les ruses de l'intelligence. La « mètis » des Grecs. Paris: Flammarion, 1974.

Whistler, James McNeill. The Correspondence of James McNeill Whistler. https:// www.whistler.arts.gla.ac.uk/correspondence/freetext/display/? cid=6591\&q=analine\&year $1=1829 \& y e a r 2=1903 \& r s=1$

Wilde, Oscar. The Collected Works of Oscar Wilde. Ed. Robert Ross. London: Routledge-Thoemmes Press, 1993 (1908), 15 vols. 


\section{NOTES}

1. Aniline is a toxic compound which was first discovered in 1826. But it was the chemist William Henry Perkin's invention of mauveine in 1856 which radically transformed the industrial textile industry as it quickly enabled a new rainbow of artificial colours to replace the more expensive organic dyes. On Perkin's "mauve", its multiple applications (commercial, artistic, medical etc.) and its discussion in the contemporary press, see Garfield (2000).

2. This is the title of the first chapter of Regina Lee Blaszczyk's study of The Color Revolution (2012).

3. I am very grateful to Adeline Grand-Clément, Arnaud Dubois and Jean-Baptiste Eczet for their invaluable advice on this piece, written while we were co-editing a volume devoted to comparative approaches to the rainbow. See Dubois et al. (forthcoming).

4. See Lichtenstein: "Matérielle, la couleur a toujours été perçue à travers les catégories ontologiquement déficientes de l'éphémère et du hasard" (74).

5. "Why the Colours of the Rainbow appear in falling drops of Rain, is also from hence evident". (Newton 3083-4).

6. According to Sean F. Johnston (2001: 27): "Chemists began using the term colorimetry in the 1860 s to refer to the determination of the quantity or concentration of a substance by the colour it imparted to a solution".

7. Volume number precedes page number in all subsequent quotes for multi-volume references. I am very grateful to Helen Glanville for pointing out this reference to me.

8. In his analysis of John Everett Millais's Blind Girl (1856) which features a sacred double rainbow felt rather than seen by the blind beggar, Ruskin refuses to address the question of the painter's materials: "The freshly wet grass is all radiant through and through with the new sunshine; full noon at its purest, the very donkeys bathed in the rain-dew, and prismatic with it under their rough breasts as they graze; [...] Very quiet she is, - so quiet that a radiant butterfly has settled on her shoulder, and basks there in the warm sun. [...] Any careful readers of my recent lectures at Oxford know that I entirely ignore the difference of material between oil and water as diluents of color, when I am examining any grave art question: nor shall I hereafter, throughout this paper, take notice of it." (Ruskin, "The Three Colours of PreRaphaelitism" v. 34: 150-1).

9. Since the Renaissance, Venice - a major point of entry of pigments and dyes - had always been considered as the land of colour. On Ruskin and the colours of Venice, see Bullen (2005).

10. Aristotle also believed that the rainbow was composed of three colours.

11. Hunt was particularly suspicious as to the use of aniline compounds in artists's pigments.

12. For an analysis of this passage full of Homeric echoes, see Adeline Grand-Clément (forthcoming).

13. Keats did not read Greek and therefore had an "instinctive" rather than a purely intellectual relation to the Hellenic heritage according to Davreu (1990: 11).

14. See Lichtenstein (1999: 61-2): "Si Chroma nomme la couleur, Poikilos qualifie tout ce qui est bariolé, c'est à dire, si l'on suit la logique du texte platonicien, non seulement le mélange des couleurs mais les couleurs elles-mêmes en tant qu'elles sont toutes des mélanges. [...] La couleur n'est qu'un effet de couleurs et c'est pourquoi elle apparaît suspecte aux philosophes, la brillance de son fard et le charme de son éclat lui conférant ce redoutable pouvoir de séduction qui caractérise tout ce qui est poikilos. Comme le renard qui est poikilos, mais aussi le serpent et le poulpe, tous les animaux qui attirent leur proie grâce à ses pièges souples et ondoyants." See also Vernant and Détienne (1974: 25-6).

15. In turn, Jane Ellen Harrison's reflections on ancient art and ritual were a major influence on D.H. Lawrence for his novel The Rainbow (1915).

16. "The Greek conviction, that all nature, especially human nature, is not entirely melodious nor luminous; but a barred and broken thing: that saints have their foibles, sinners their forces; that 
the most luminous virtue is often only a flash, and the blackest-looking fault is sometimes only a stain: and, without confusing in the least black with white, they can forgive, or even take delight in things that are like the nebris, dappled."

17. On the symbolic connotations of the Greek purple, see Grand-Clément (2011: 117 et sq.).

18. In order to emulate this fashionable dye, the Impressionists used the new cobalt violet rather than an aniline-based pigment. However, in a letter to his wife, the painter Whistler describes the impressionist mauve as "analine", as if to underline the excremental nature of the colour made from industrial refuse. [11 June 1891?] Glasgow University Library, MS Whistler W584. See the online correspondence of Whistler: https://www.whistler.arts.gla.ac.uk/correspondence/ freetext/display/?cid=6591\&q=analine\&year1=1829\&year2=1903\&rs=1

19. Indigo was the name of the seventh colour in Newton's rainbow, a colour which, rather surprisingly, refers to the Indian dye which in the early 17th century was starting to be imported to England.

20. Olive Custance, who would marry Lord Alfred Douglas in 1902, composed two volumes of poetry entitled "Opals" (1897) and "Rainbows" (1902) in a very similar vein. In 1899, the artist George Frampton also sculpted an ivory and bronze "Lamia", crowned with iridescent opals, possibly as a homage to the recently rediscovered polychromy of ancient Greek sculpture.

21. The chemical process is described in The Artist, $1^{\text {st }}$ April 1892, 114-5. I wish to thank Catherine Maxwell for this reference.

\section{ABSTRACTS}

In his 1993 book retracing the history of synthetic dyestuffs, Anthony S. Travis describes the $19^{\text {th }}$ century chemists who devised new aniline dyes for the expanding textile industry as "rainbow makers". By conflating the materiality of coloured textiles and the prismatic hues of the sacred bow, Travis may have been trying to vindicate a scientific entreprise which many late $19^{\text {th }}$ century artists and writers had shunned, echoing John Keats's denunciation of the "unweaving" of the rainbow by modern science. This article explores the poetic instability generated by the $19^{\text {th }}$ century colour revolution in the works of John Ruskin, William Morris, Walter Pater and Oscar Wilde so as to shed light on the complex reception of modern artificial colouring practices as opposed to the Homeric colour-sense.

Dans son ouvrage de 1993 retraçant l'histoire des colorants de synthèse, Anthony S. Travis décrit les chimistes du $19^{\text {ème }}$ siècle à l'origine des couleurs d'aniline destinés à une industrie textile en pleine expansion comme des "faiseurs d'arcs-en-ciel". En associant ainsi la matérialité des textiles colorés et les couleurs prismatiques de l'arc divin, Travis souhaitait sans doute défendre une entreprise contre laquelle de nombreux artistes et écrivains victoriens s'étaient insurgés, reprenant à leur compte la dénonciation keatsienne du détissage de l'arc-en-ciel par la science moderne. Cet article explore l'instabilité poétique générée par cette révolution chromatique dans l'œuvre de John Ruskin, William Morris, Walter Pater et Oscar Wilde afin de mettre en lumière les modalités complexes de réception de ces nouvelles pratiques colorantes, contrastant avec les couleurs d'Homère. 


\section{INDEX}

Keywords: Victorian literature, Victorian painting, fin de siècle, rainbow, prismatic colour, pigments, aniline dyes, chromatic materiality, poikilia, chemistry, classical reception studies, Homer, Newton Isaac, Wilde Oscar, Ruskin John, Pater Walter, Hunt William Holman, Morris William, Keats John

Mots-clés: littérature victorienne, peinture victorienne, fin de siècle, arc-en-ciel, couleur prismatique, pigment, colorants d'aniline, matérialité chromatique, poikilia, chimie, réception de l'Antiquité, Homère, Newton Isaac, Wilde Oscar, Ruskin John, Pater Walter, Hunt William Holman, Morris William, Keats John

\section{AUTHOR}

\section{CHARLOTTE RIBEYROL}

Charlotte Ribeyrol is Associate Professor at the Sorbonne University in Paris and a Member of the Institut Universitaire de France. Her main field of research is the reception of the colours of the past in Victorian painting and literature. Her monograph on the Hellenism of Swinburne, Pater and Symonds entitled "Etrangeté, passion, couleur", L'hellénisme de Swinburne, Pater et Symonds came out in 2013 and she has since co-edited two volumes on the subject of Victorian paganism in international peer-reviewed journals: Antique bodies in Nineteenth Century British Literature and Culture. (with C. Bertonèche) Miranda, n 11, 2015 and Late Victorian Paganism. (with C. Murray) Cahiers Victoriens et Edouardiens (2015). She is also a contributor to the forthcoming volume Pater the Classicist (OUP, 2017). In 2014-2016 she co-directed a major interdisciplinary project on chromatic materiality (POLYRE, IDEX Sorbonne Universités) with chemists and archeologists, which led to the publication of a collection of essays entitled The Colours of the Past in Victorian England (Oxford, Peterlang, 2016). She currently holds a Marie Curie Fellowship at Trinity College, Oxford (2016-2018) to write her new book on the colours of William Burges's Great Bookcase. Contact: ribeyrolc [at] gmail.com 